\title{
CRITICAL REACTION FORCES IN THE Z-KINEMATIC LOADERS
}

\author{
Janko Jančevski \\ Faculty of Mechanical Engineering, "Ss. Cyril and Methodius" University in Skopje, \\ P.O. Box 464, MK-1001 Skopje, Republic of North Macedonia \\ janko.janchevski@mf.edu.mk
}

\begin{abstract}
A b s t r a c t: The loading processes in industry and mining are the crucial issue in achieving high economic performances. So, there are various kinematic mechanisms and concepts for loading machines. Besides of the loaders with continual work, in this article only one of the most used concepts of loaders, the Z-kinematic loaders are presented. The joints reaction forces during a working process can be extremely high, so it is very important to create simulation computer programs for force and stress calculation in the joints of a loader. Some positions and working loads can produce critical stresses and deformations.
\end{abstract}

Key words: Loaders; Z-kinematic: Reaction-forces

\section{КРИТИЧНИ РЕАКЦИИ КАЈ ТОВАРАЧИТЕ ОД ВИДОТ Z-KINЕМАТІК}

А п с т р а к т: Претоварните процеси во индустријата и рударството се исклучително важни за постигнување високи економски перформанси. Така, постојат голем број кинематички механизми за товарните машини. Иако постојат товарачи со континуирана работа, во овој труд е опфатен еден од најчесто користените концепти кај товарачите - тоа е таканаречен Z-kinematik. Реакциите во зглобовите во тек на еден работен процес се со екстремно високи вредности, така што е многу важно да се креираат компјутерски програми за пресметка на силите и напрегањата во зглобовите на товарачите. Во некои положби на работниот механизам, поради товарот можат да се достигнат критични напрегања и деформации.

Клучни зборови: товарачи; Z-inematik; реакции; сили

\section{INTRODUCTION}

Loaders work in very different conditions depending on the loading material, and also geometrical, kinematic and dynamic characteristic of the working mechanism (Figure 1). Forces acting in the machine also depends on the position of the elements. Thus, it is very important to create simulation program which makes animation of a loader in the entire working area, presenting positions of the working mechanism, and also reaction forces (shows numerically $(\mathrm{kN})$ and like red arrows on the screen).

The program CATF3.EXE (2019, Windows OS, $\mathrm{C} / \mathrm{C}^{++}$) is based on older version CAT.EXE (1994, DOS OS, written in C language). In the both programs the TRET [1] module is essential for fast calculation and animation without fleshing or blinking. CATF3.EXE simulation of a Z-kinematic loaders gives an instant information about positions and forces of loader's elements: there are possibilities to many parameter modifications and makes a visual analyse for all of the working regimes and cases.

CATF3.EXE includes a special program module DIADF, for reaction force calculation. Nowadays computer processors are fast enough to make excellent calculation and animation besides of large amount of equations.

Program module TRET [1] enables fast calculation position and shows it on the screen even on older computers. The calculation of every position of a complex linkage in loader and hydraulic exca- 
vators last less than $0.05 \mathrm{sec}$. With traditional calculation methods this is impossible to achieve.

However, addition including a DIADF program module $(\mathrm{C} / \mathrm{C}++)$ for reaction force calculation for $\mathrm{PC}$ processor frequency less than $1 \mathrm{GHz}$, makes the animation slower, so CAT.EXE, RD180.EXE and many others simulation programs, before 2005, do not include program module for force calculation DIADF (Figures.2, 3 and 4).

The mechanism presented on the Figure. 4 is one of the most complex in loaders, usually used in long reach loading.
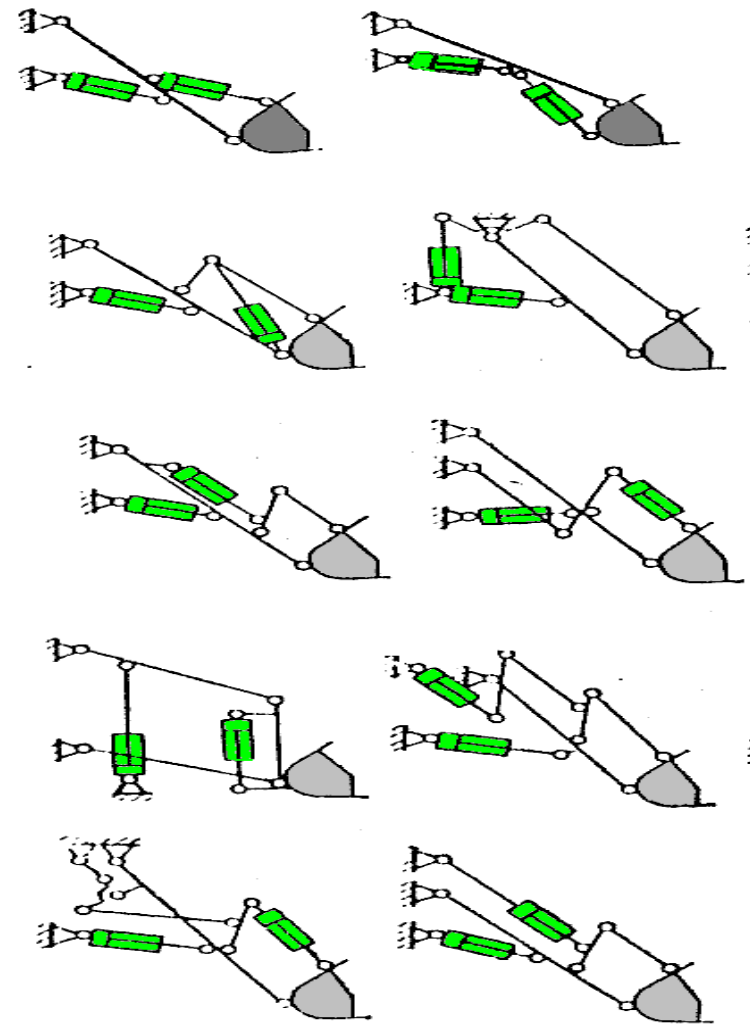

Fig. 1. Schematics of some working mechanisms of loaders

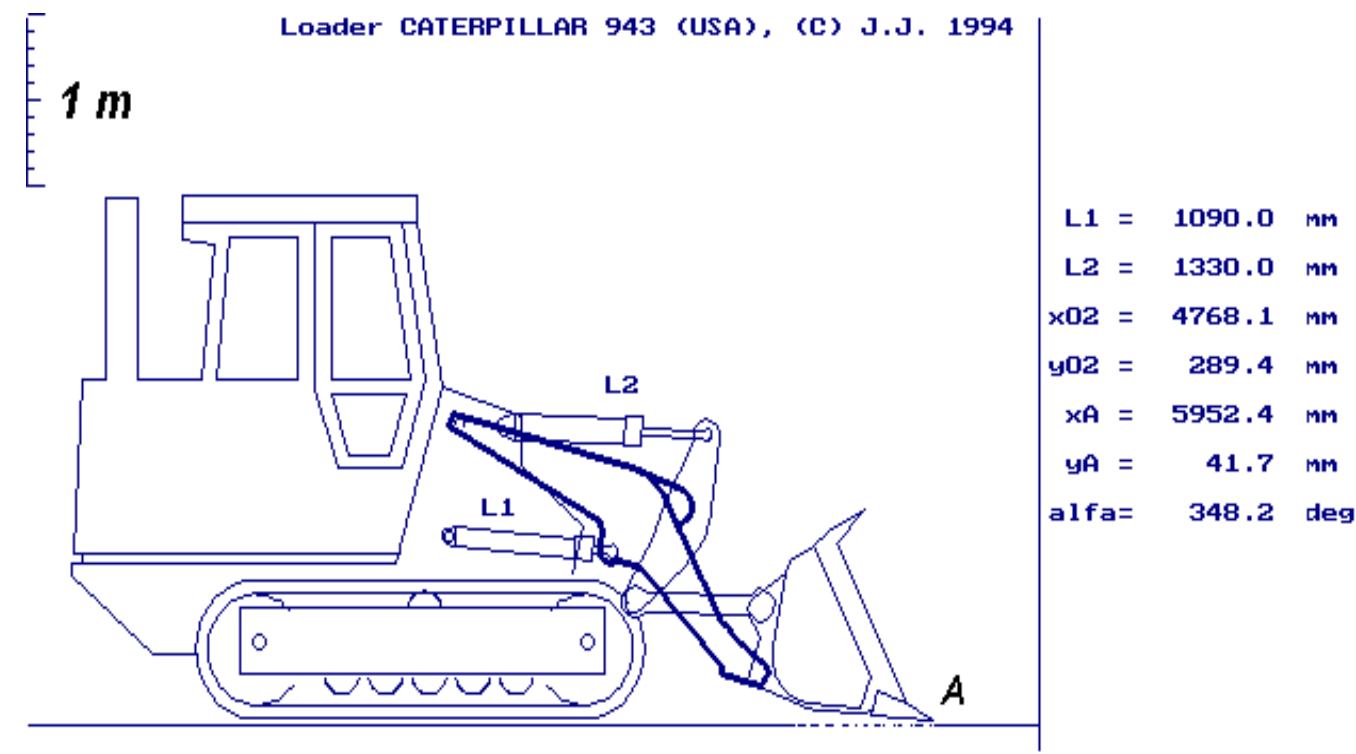

Fig. 2. Computer animation sequence of Z-kinematic Loader Caterpillar (1994, CAT.EXE, DOS OS, C-language) 


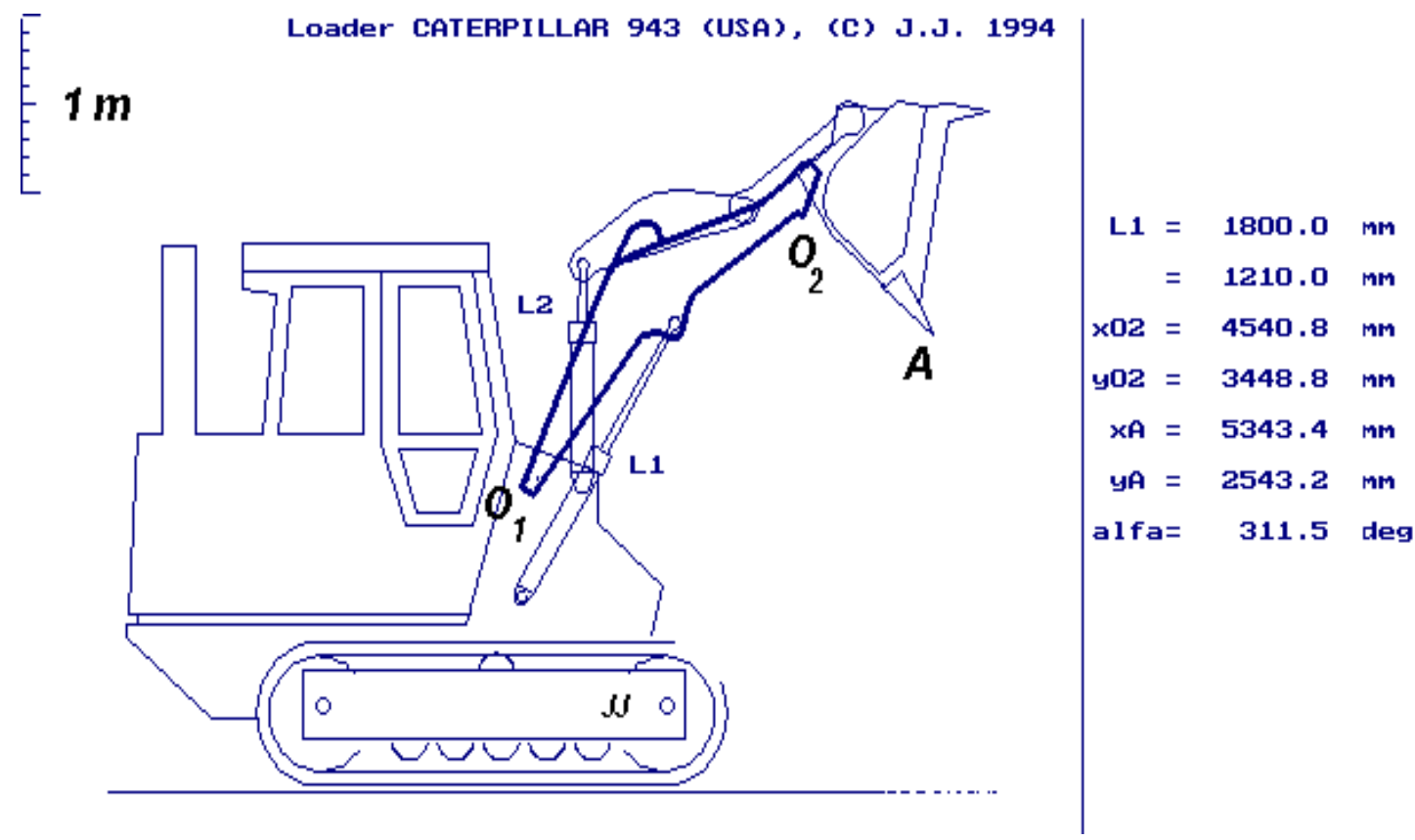

Fig. 3. Computer animation sequence of Z-kinematic Loader Caterpillar (1994, CAT.EXE)

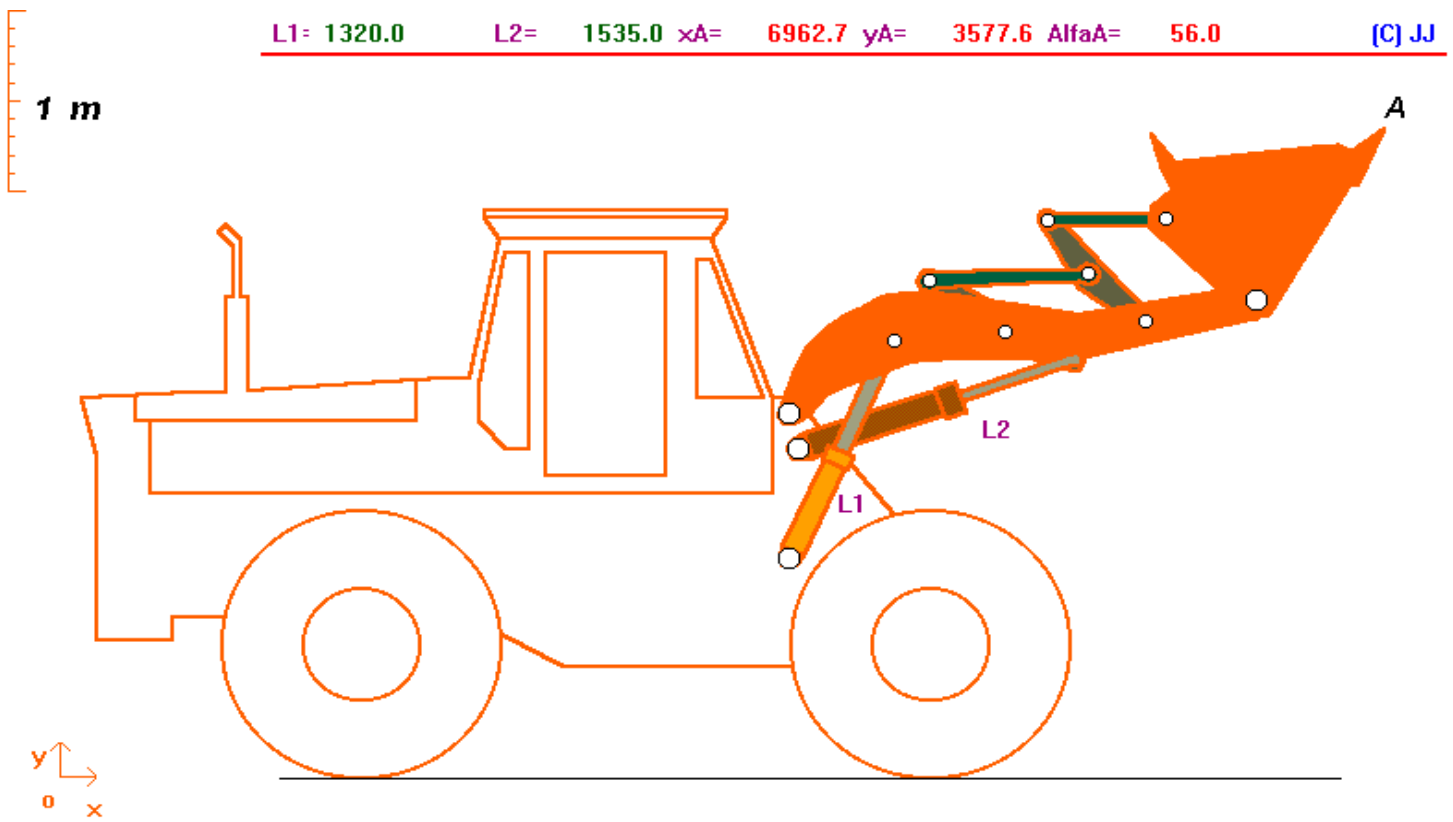

Fig. 4. Computer animation sequence of much complex working mechanism wheel Loader RD 180 (2004, RD180.EXE, Windows OS, C/C++)

\section{Z-KINEMATIC LOADERS}

Z-kinematic concept is much simple, and also have better force transmissions from hydraulic cylinders to linkage and bucket teeth and also bigger force for lifting the full bucket.

Figures 5 and 6 show testing of a loaders in Cement factory in Skopje.
In case of loading some homogenous material, the forces on the linkage are low and mid-level. But there are other situations and position of working mechanism, where reaction forces in joints have extremely high values. Simulation of outer force Fw on the teeth in lower bucket position, result of CATF3.EXE Program. Reaction forces are given in $\mathrm{kN}$, and also shown as red arrows. (Figures 7, 8 and 9). 


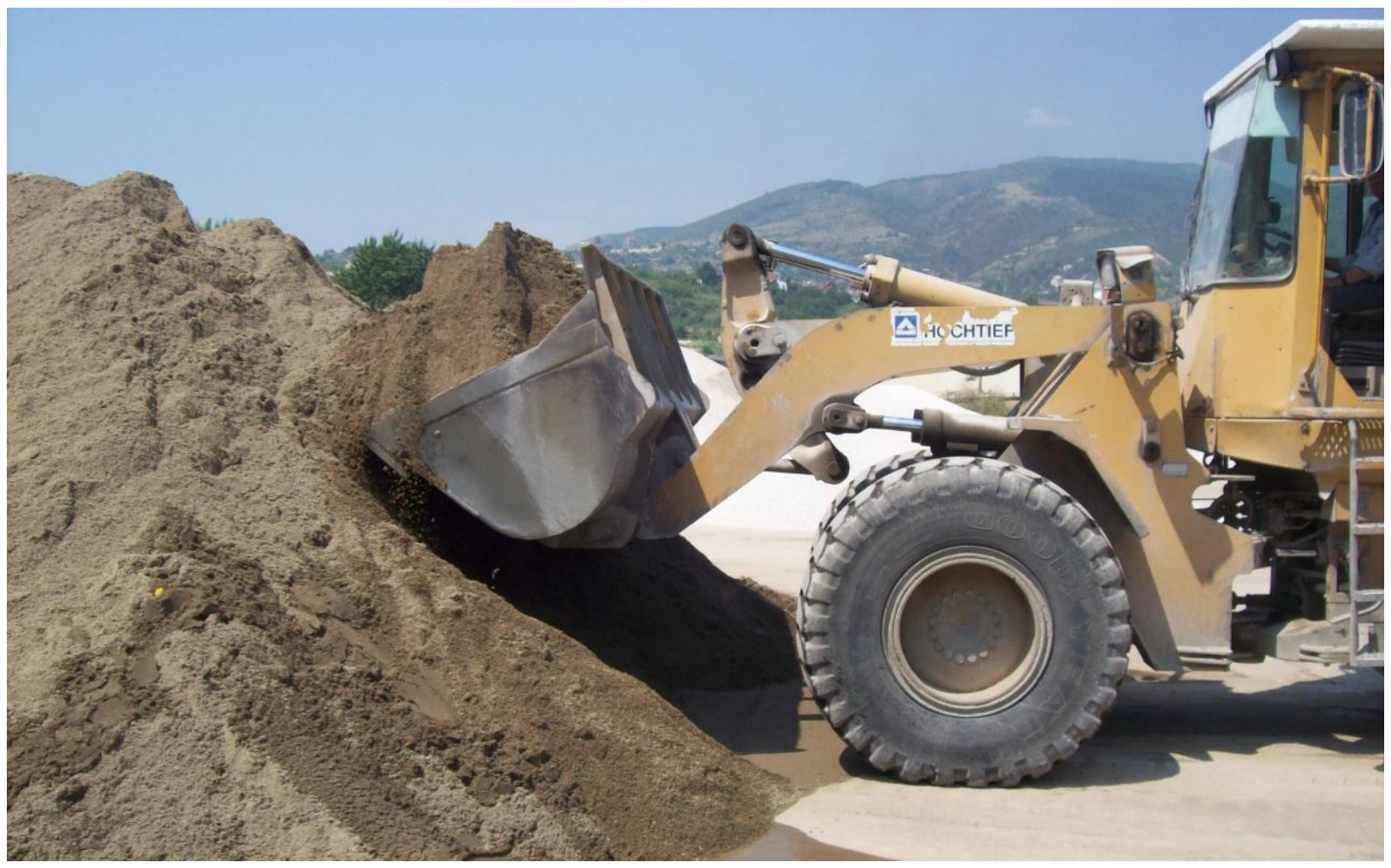

Fig. 5. Testing of a Z-kinematic loader in Skopje Cement industry "Titan" -Usje (Photo.J. Janchevski)

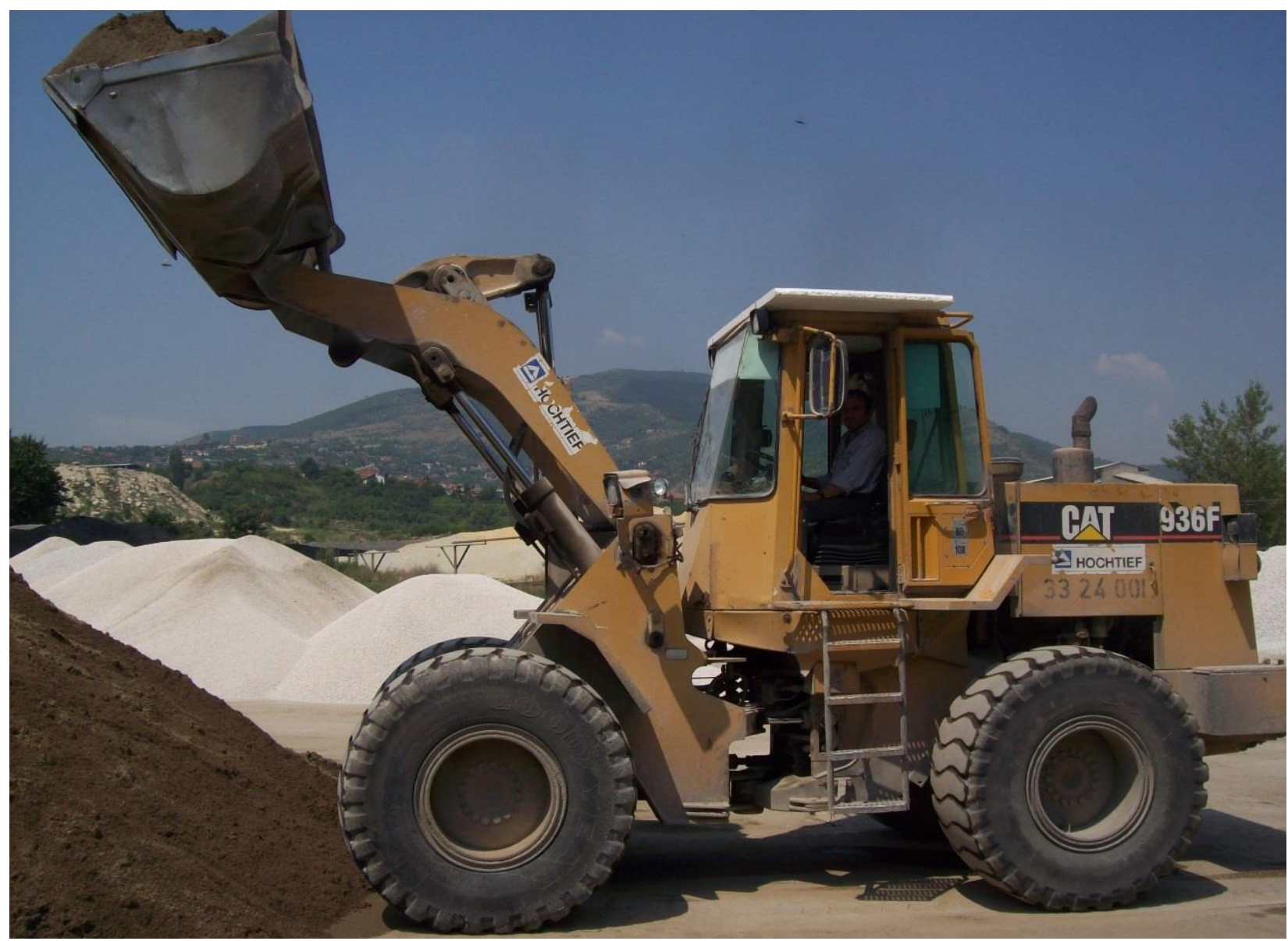

Fig. 6. Testing of a Z-kinematic loader in Skopje Cement industry "Titan"-Usje (Photo:.J. Jančevski) 


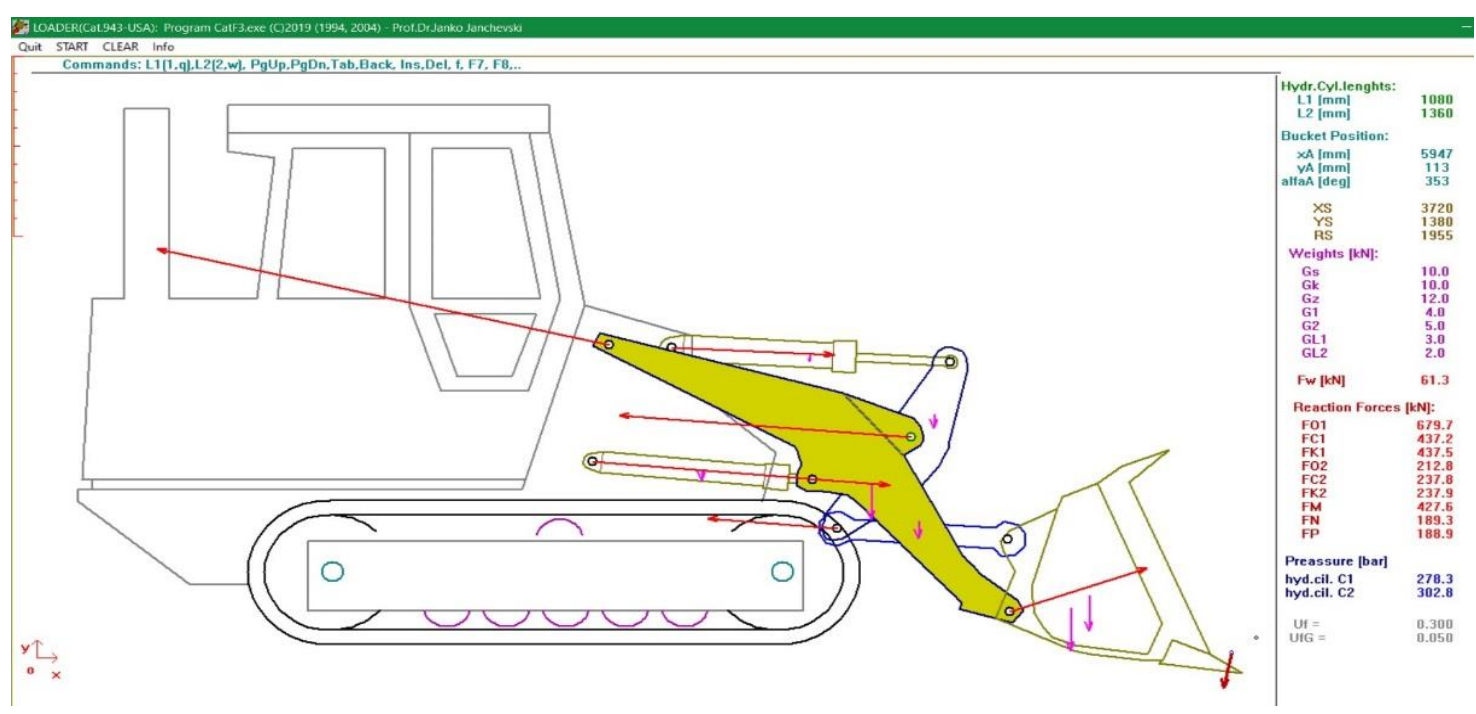

Fig. 7. Low position of working equipment of a loader, Forces are shown on two manner (2019 CATF3.EXE).

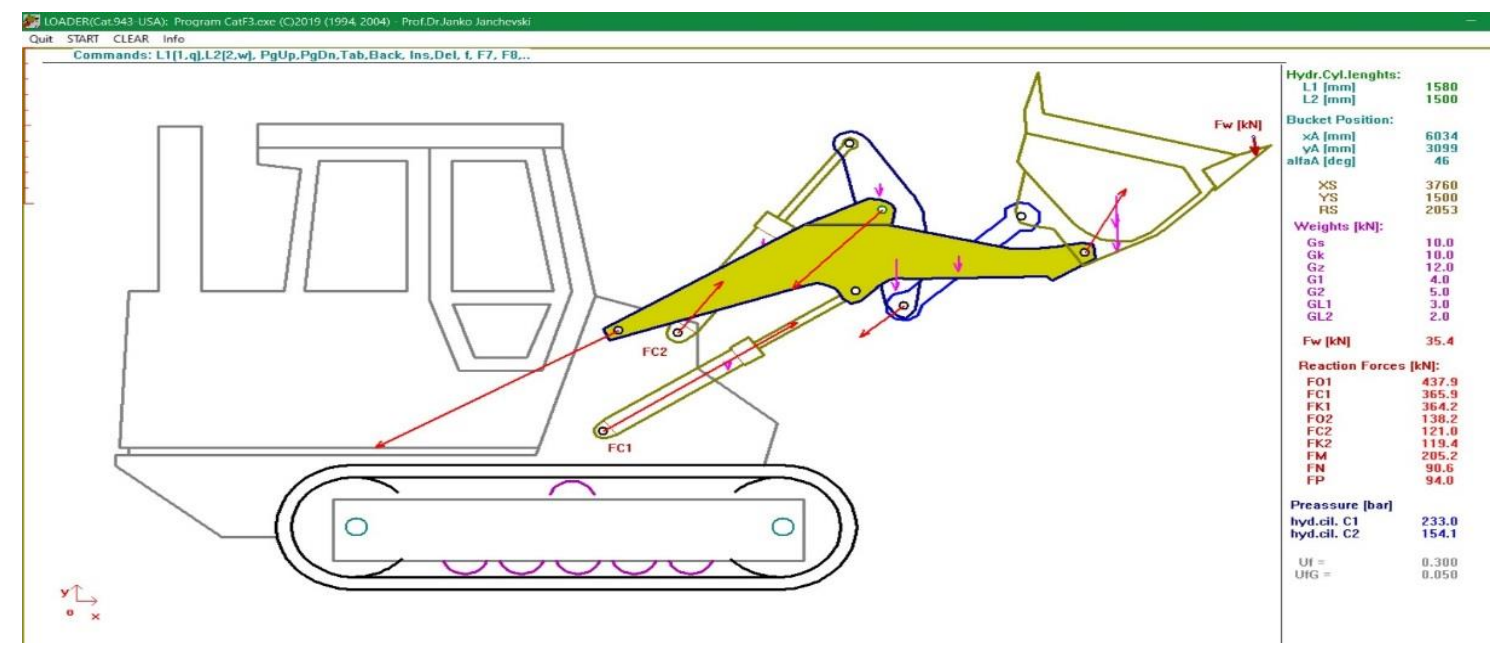

Fig. 8. Upper position of the bucket. Preview of the reaction forces.

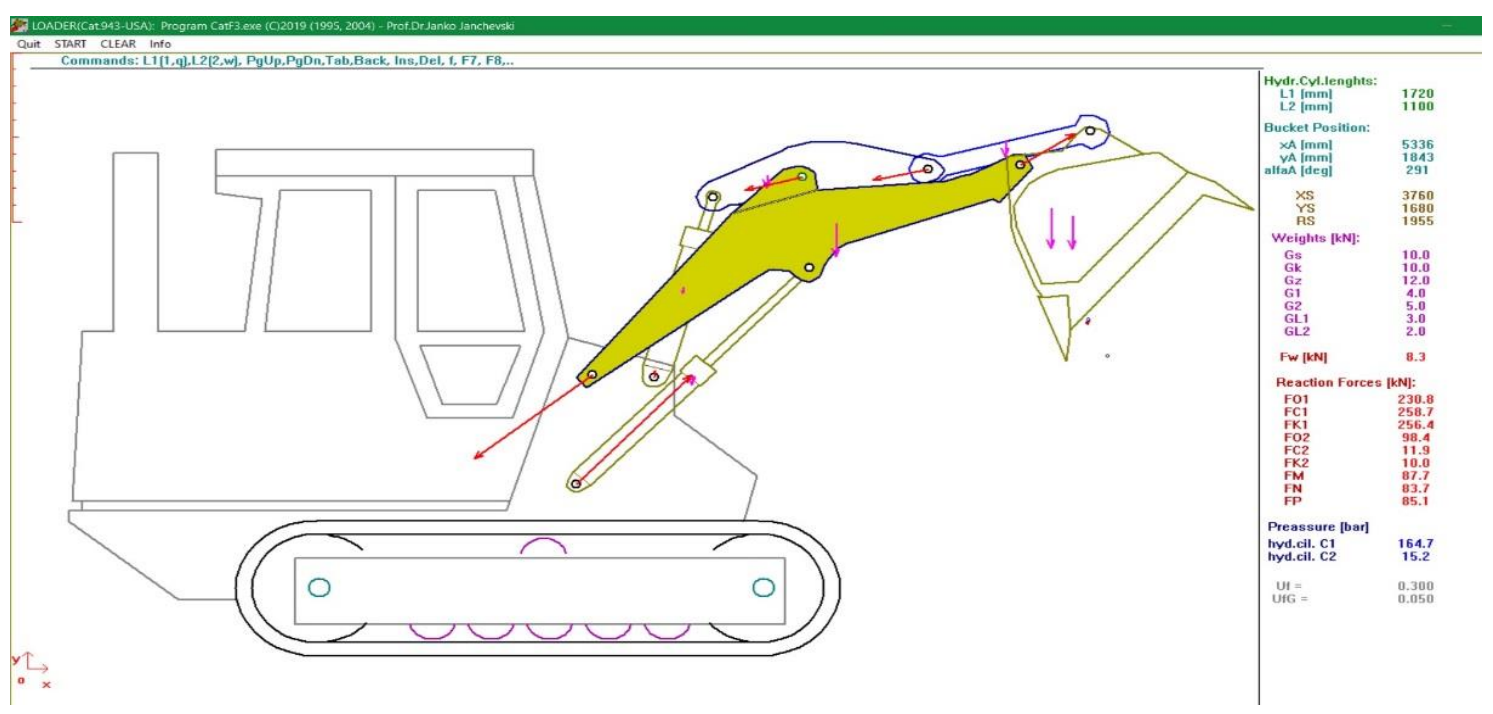

Fig. 9. Dumping position of the bucket. Preview of the reaction forces. 
Those two images show positions of animations executed by program CATF3. The weight of equipment and loading material into bucket, and position of gravity centres, have big impact on reaction forces.

In the upper position of the bucket the outer force $\mathrm{Fw}$ is zero and has no influence. CATF3 enables the analysis of many positions and find the critical forces in any joint of equipment.
It is clear that reaction forces are very strong. If they are not limited by hydraulic, mechanical or electronic devices, probably they will destroy some of elements.

Figures 10 and 11 show a total deformation of pistons and hydraulic cylinders after excessive forces $\mathrm{F}_{\mathrm{C} 2}$ and $\mathrm{F}_{\mathrm{K} 2}$ on the both of second hydraulic cylinder (twin-cylinders). The loader is a Z-kinematic ULT 220 (14. Oktober, Serbia), used for loading operations Steel company in Skopje.

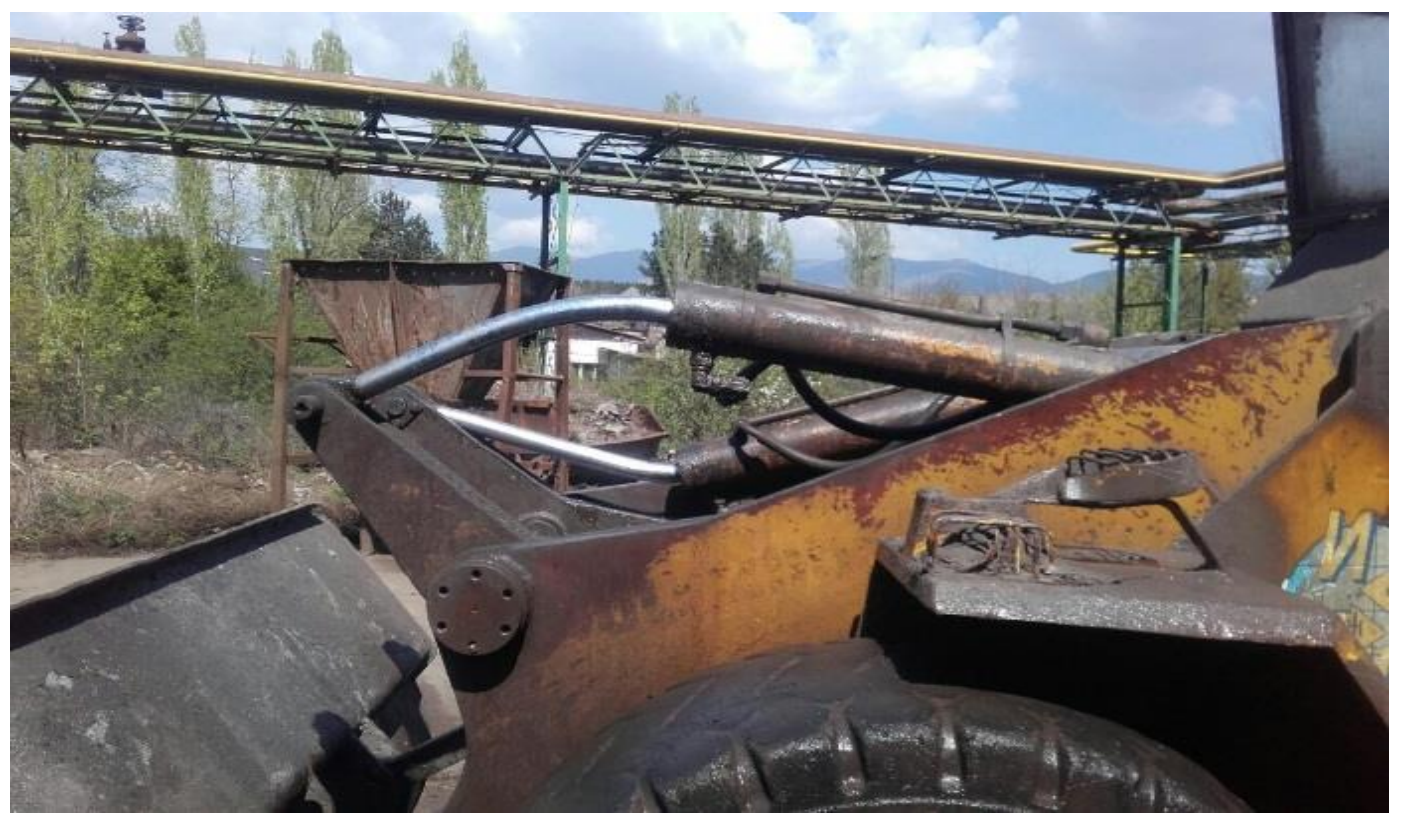

Fig. 10. Total deformation of the piston rods in both hydraulic cylinders on Z-kinematic loader ULT 220 in Skopje Steel industry (Photo. D. Brkovski)

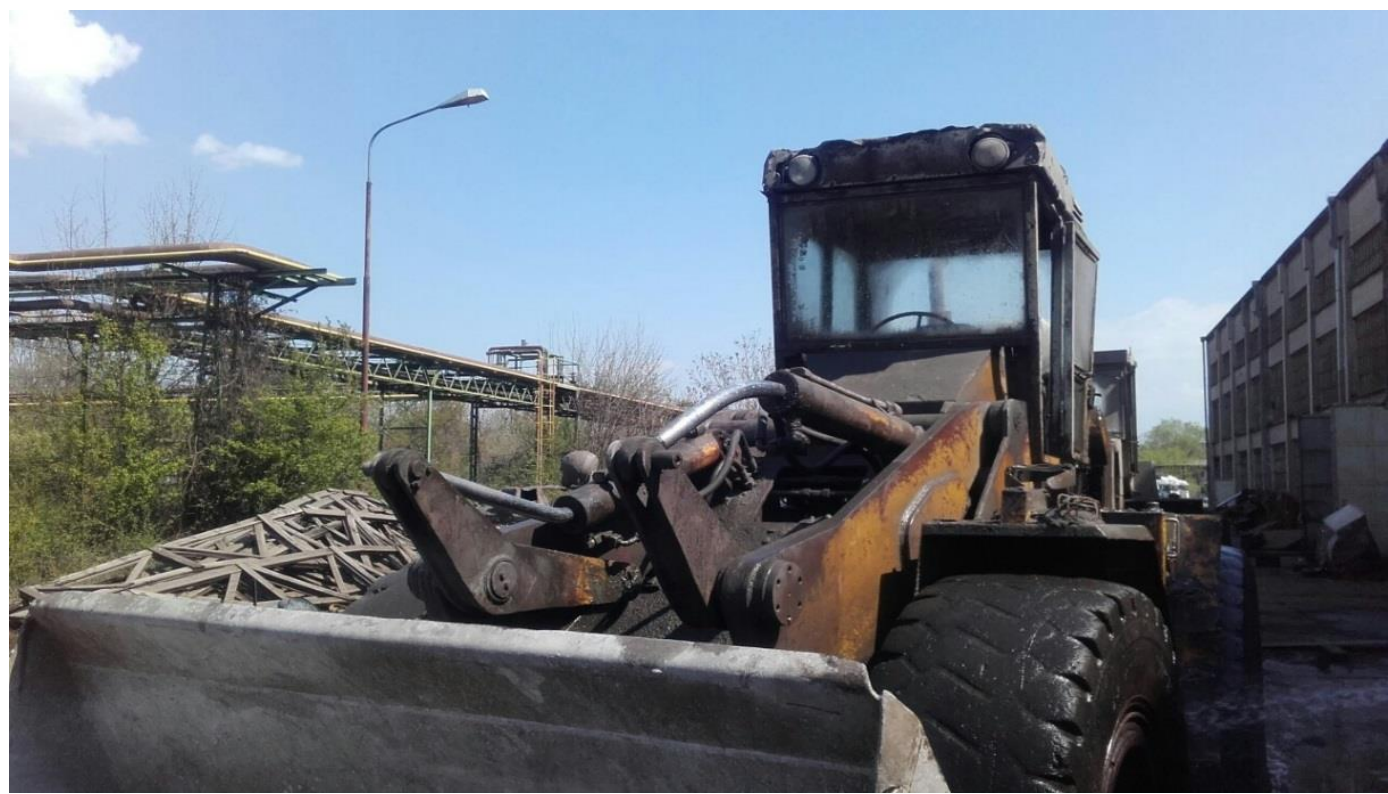

Fig. 11. Deformation of the piston rods in the double hydraulic cylinders on Z-kinematic loader ULT 220 in Skopje Steel industry (Photo. D. Brkovski) 


\section{CONCLUSIONS}

Loaders are heavy duty machines used in mining, civil industry, agriculture etc. Especially in the mining, forces on the working mechanisms reaches very high intensity in wide diapason of angles. The deformations and crashes are very possible. Designers of that kind of machines must use computer simulation programs, to reduce experiments costs. CATF3 is one of those simulation programs. The associating files included to the program enables modification of some geometrical parameters to get the best results. This can also be used for projecting pressure limitation levels in the safety devices. Based on TRET methodology, there are some other more universal simulation software.

\section{REFERENCES}

[1] Jančevski, J. (1996): Algorithm approach for synthesis and analysis of the working mechanism of the loaders. $\mathrm{PhD}$ Dissertation, Faculty of Mechanical Engineering, Skopje.

[2] Janoshevic, D., Milic, P., Jovanovic, V., Pavlovic, J. (2014): Kinematic and dynamic simulation of the wheel loaders with the Z-bar working mechanism, IMK-14, Istrazivanje i razvoj, University of Nish.

[3] Shen, J., Wang, G., Bi, Q., Qu, J. (2013) A comprehensive genetic algorithm for design optimization of Z-bar loader working mechanism. Journal of Mechanical Science and Technology, Vol. 11, No. 27, pp. 3381-3394

[4] Jančevski, J. (2011): Trajectory Computer Control of the Complex Mechanical Systems, $9^{\text {th }}$ International Science Symposium - Project Learning, Portoroz, Slovenia. 
